\title{
Correction to: Psychosocial Interventions for Newly Arrived Adolescent Refugees: A Systematic Review
}

\author{
Nora Hettich ${ }^{1}\left[\right.$ [ Franziska Anna Seidel ${ }^{2} \cdot$ Lydia Yao Stuhrmann $^{3}$ (1)
}

Published online: 29 September 2021

(c) The Author(s) 2021

\section{Correction to: Adolescent Research Review (2020) 5:99-114 https://doi.org/10.1007/s40894-020-00134-1}

The article "Psychosocial Interventions for Newly Arrived Adolescent Refugees: A Systematic Review" written by Nora Hettich · Franziska Anna Seidel · Lydia Yao Stuhrmann was originally published Online First without Open Access. After publication in volume 5, issue 2, page 99-114 the author decided to opt for Open Choice and to make the article an Open Access publication. Therefore, the copyright of the article has been changed to (C) The Author(s) 2021 and the article is forthwith distributed under the terms of the Creative Commons Attribution 4.0 International License, which permits use, sharing, adaptation, distribution and reproduction in any medium or format, as long as you give appropriate credit to the original author(s) and the source, provide a link to the Creative Commons licence, and indicate if changes were made. The images or other third party material in this article are included in the article's Creative Commons licence, unless indicated otherwise in a credit line to the material. If material is not included in the article's Creative Commons licence and your intended use is not permitted by statutory regulation or exceeds the permitted use, you will need to obtain permission directly from the copyright holder. To view a copy of this licence, visit http:// creativecommons.org/licenses/by/4.0. Open access funding enabled and organized by Projekt DEAL.

The original article has been corrected.

Open Access This article is licensed under a Creative Commons Attribution 4.0 International License, which permits use, sharing, adaptation, distribution and reproduction in any medium or format, as long as you give appropriate credit to the original author(s) and the source, provide a link to the Creative Commons licence, and indicate if changes were made. The images or other third party material in this article are included in the article's Creative Commons licence, unless indicated otherwise in a credit line to the material. If material is not included in the article's Creative Commons licence and your intended use is not permitted by statutory regulation or exceeds the permitted use, you will need to obtain permission directly from the copyright holder. To view a copy of this licence, visit http://creativecommons.org/licenses/by/4.0/.

Publisher's Note Springer Nature remains neutral with regard to jurisdictional claims in published maps and institutional affiliations.

The original article can be found online at https://doi.org/10.1007/ s40894-020-00134-1.

Nora Hettich

Nora.hettich@uni-kassel.de

1 Department of Human Sciences, Institute for Educational Science, Psychoanalysis, University of Kassel, Arnold-Bode-Straße 10, 34127 Kassel, Germany

2 Department of Human Sciences, Institute for Social Work and Social Welfare, University of Kassel, Arnold-Bode-Straße 10, 34127 Kassel, Germany

3 Department of Child and Adolescent Psychiatry, Psychotherapy and Psychosomatics, University Medical Center Hamburg-Eppendorf, Martinistraße 52, 20246 Hamburg, Germany 